International Journal of Business Management and Economic Review

Vol. 4, No. $03 ; 2021$

ISSN: 2581-4664

\title{
THE EFFECT OF TOURIST EXPERIENCE AND DESTINATION IMAGE ON REVISIT INTENTION THROUGH TOURIST SATISFACTION AT TOURISM DESTINATIONS IN ACEH BESAR DISTRICT
}

\author{
Rohana Sari, Muhammad Adam and Syafruddin Chan \\ Management Department, University of Syiah Kuala, Indonesia \\ http://doi.org/10.35409/IJBMER.2021.3273
}

\begin{abstract}
This study aimed to examine the effect of tourist satisfaction as a mediation on the relationship between tourist experienceand destination image on the revisit intention at tourism destinations in Aceh Besar District, Indonesia. The questionnaire data was collected online as much as 220 samples. Based on the result through SEM analysis, it shows that Tourists' experience Affects Significantly tourists' satisfaction, Destination Image Affects Significantly Tourist Satisfaction, Tourist Experience Affects Significantly Revisit Intention, Destination Image Affects Significantly Revisit Intention, Tourist Satisfaction Affects Significantly Revisit Intention, Tourist Experience Affects Significantly Revisit Intention through Tourist Satisfaction, and Destination Image Affects Significantly Revisit Intention through Tourist Satisfaction. These results indicate that the evidence of the research model that has been carried out is still following previous theories of causality, especially on the object under study. The novelty of the research is in a combination of previous causality theories which are combined into a model to be investigated on new objects. These results contribute to the world of academia, which can be a reference for further researches. For further research, it is hoped that it will be able to develop a research model by adding new variables such as destination image or tourist gender. Besides, the research location and different characteristics of respondents in the analysis will also enrich the existing empirical evidence about the effect of tourist experience and destination image on revisit intention through tourist satisfaction.
\end{abstract}

Keyword: Tourist Experience, Destination Image, Revisit Intention, Tourist Satisfaction.

\section{INTRODUCTION}

Aceh Besar District, in Indonesia, is rich in tourist destination objects that are diverse and evenly distributed throughout the region making the district the second largest tourist destination in Aceh Province after Sabang City. The number of tourists increased from 2015 to 2017. A very significant increase in tourist visits occurred in 2015, where the increase of visits was dominated by domestic tourist visits. However, the increase in the number of tourist visits every year in Aceh BesarDistrict does not indicate that there is an increase in tourists to revisit intention.

The problem regarding the low revisit intention of tourists can be caused by various factors. One of the possible factors is the low level of tourist satisfaction based on their experience when visiting a destination. Tourist dissatisfaction can cause customer exits and it can 


\section{International Journal of Business Management and Economic Review}

Vol. 4, No. 03; 2021

ISSN: 2581-4664

potentially reduce the number of tourist visits to a tourist destination in the long term. Conversely, high satisfaction of tourists during and after visiting certain tourist destinations can give a positive image and increase revisit intention for tourists in the future (Sulastri, Rapini, \& Kristiyana, 2018).

Studies investigating the factors that influence revisit intention is not something new in tourism research. Several previous studies have shown that revisit intention is influenced by the image of the destination, the overall satisfaction experienced by tourists at certain destinations is also considered a predictor of revisit intention(Valle, Silva, Mendes, \& Guerreiro, 2006), (Kozak \& Rimmington, 2000) and (Bigné, Sánchez, \& Sánchez, 2001).

On the other hand, the tourist experienceis major construction in travel and tourism research and the determination of tourist destinations (Oh, Fiore, \& Jeong, 2007). (Hosany \& Witham, 2009) stated that the involvement of tourists that shape the experience of traveling can affect tourist satisfaction and intention to recommend to others. (Um, Chon, \& Ro, 2006) in their study revealed that tourist satisfaction is a mediating construct between tourist motivation and revisit intention. In line with this,(Yoon \& Uysal, 2005)also proposed that tourist satisfaction is both a predictor and a moderating variable between revisit intention and destination image.

This research was conducted to validate the variables of the tourist experience, destination image, satisfaction, and tourist revisit intention by conducting surveys in different places or countries with samples from various population sites to address the possible biasfrom previous studies (Kastenholz, Carneiro, Marques, \& Loureiro, 2018) and (Zhang, Wu, \& Buhalis, 2018). In addition to estimating this causal model, this study also aimed to identify how the observed variables can describe the relationship between variables and their influence in determining tourist revisit intention. With a more complex model, this study has the advantage of allowing a better understanding of tourist behavior in bridging the gaps in previous studies (Valle et al., 2006); (Oh et al., 2007) and (Um et al., 2006).

\section{LITERATURE REVIEW AND HYPOTHESIS Revisit Intention}

Behavioral intention is the planning of an intention to carry out a certain behavior (Richard \& Vanessa, 2007), (Ryan \& Glendon, 1998). It is argued that when there is a strong intention for someone to engage in a certain behavior, that person is more likely to do the behavior (Ajzen, 2002). In the tourism and recreation sector, this takes the form of buying back tourism services or recreational services or revisiting tourist destinations or attractions (Pratminingsih, Rudatin, \& Rimenta, 2014).

(Som, Marzuki, Yousefi, \& AbuKhalifeh, 2012) explained that revisit intentionis: "the evaluation carried out regarding the travel experience or the perceived value and overall visitor satisfaction that affect future behavior in the consideration of the desire to return to the same destination and their willingness to recommend it to other people ". Similarly, (Lin, 2012), (Som et al., 2012)also maintain that there are two dimensions of revisit intention, namely:

a. The willingness to revisit: measuring the desire of tourists to revisit the same tourist destination in the future.

b. Recommending it to others:measuring the desire of tourists towards a destination that has been visited by recommending it and doing positive WOM to friends or relatives. 


\section{International Journal of Business Management and Economic Review}

Vol. 4, No. 03; 2021

ISSN: 2581-4664

\section{Tourist satisfaction}

Customer satisfaction is a customer's response to the evaluation that is felt after using a product by comparing the mismatches of previous expectations to the actual performance of a product (Tse \& Wilton, 1988). According to (Gaspersz, 2005), the factors that influence consumers' satisfaction and expectations consist of "needs and wants" relating tothe things that one feels when trying to make a transaction with a manufacturer's services. In general, satisfaction in the context of tourism (tourist satisfaction) is an overall evaluation of travel destinations based on what is expected (Guntoro \& Hui, 2013).

(Valle et al., 2006) stated that the perception of tourist satisfaction is a combination of several dimensions of satisfaction which include the general satisfaction felt by tourists while traveling, satisfaction with the attributes of tourist destinations (for example, transportation, accommodation, tourism product, beautiful scenery, cultural attractions, etc.) that meet their expectations.

Furthermore, (Valle et al., 2006), stated that there are three dimensions (sub-variables) which are used to measure tourist satisfaction, namely:

a. General satisfaction

Customers' satisfaction can also be estimated with one item by only measuring the overall perception of satisfaction.

b. Attribute satisfaction

In addition to global perceptions of results, the level of satisfaction can also be evaluated through certain service attributes (Mai \& Ness, 2006).

c. Meet expectations

Satisfaction can be evaluated using expectation confirmation theory in which expectations and actual goal results are compared.

\section{Tourist Experience}

Experience cannot be defined globally, every language and culture defines it differently. However, some researchers examining the concepts of experiential marketing have tried to define it more clearly. A travel experience is a mental journey that can provide memories for tourists after doing something special, or learning something new, or just pleasing themselves (Pine \& Gilmore, 2013). Moreover, (Pine \& Gilmore, 2013)explain that there are four dimensions of tourists' experience that can be distinguished by the form and the level of involvement, namely:

a. Education

The educational experiences of a tourist will affect their understanding of events that take place in a certain tourist destination. It happens because they actively participate through their minds or body interactions which will give an impact on increasing knowledge and skills.

b. Entertainment

Entertainment experiences occur when tourists passively see events or performances at a destination, such as listening to musicor reading books for pleasure.

c. Esthetics

In an aesthetic experience, tourists prefer to be in a destination in a natural environment so that they can enjoy the nature of the environment. 


\section{International Journal of Business Management and Economic Review}

Vol. 4, No. 03; 2021

ISSN: 2581-4664

d. Escapism

In general, tourism is a way for people to get out of their daily life (routines) to experience different and extraordinary experiences (non-routine life).

\section{Destination image}

Destination image has been one of the main areas of tourism research for more than four decades. An image can be further defined as beliefs, impressions, ideas, and perceptions that people have about objects, behaviors, and events (Rajesh, 2013).

Destination image is the total impression of the goal, which is a combination of components of a cognitive image, unique image, and effective image. This concept is supported by (Baloglu \& Brinberg, 1997)who stated that image components are interrelated. In other words, the image of a destination is the total impression based on the three components of the image that affect the future behavior of tourists (Qu, Kim, \& Im, 2011). Furthermore, (Qu et al., 2011) stated that there are 3 dimensions of destination image, namely:

a. Cognitive image, consisting of the number of beliefs, impressions, ideas, and perceptions owned by people to an object

b. Affective image, related to how a person feels about objects

c. The unique image, the only of its kind that is unlike any others.

\section{Research Hypothesis And Its Previous Relationship Theories}

H1: Tourists' experience Affects Significantly tourists' satisfaction

Several previous studies have shown that the experiential dimension in diverse contexts can contribute to satisfaction. In a study conducted by (Semrad \& Rivera, 2018) and (C.-C. Huang, Yen, Liu, \& Chang, 2014), it was found that in the music festival and the context of cultural performances there was a construct of the tourist experiencewhich integrates the four dimensions of the touristexperience showing positive impacts on visitor satisfaction.

\section{H2: Destination Image Affects Significantly Tourist Satisfaction}

Destination image, in general, is an image in the form of tourist attraction, accommodation, accessibility, facilities, activities, local communities, and shopping centers which give an impact on tourist satisfaction. Image, attitude, motivation, sceneries, recreational services, and equipment are attributes that affect tourist satisfaction (Quintal \& Phau, 2008); (Lee, Lee, \& Lee, 2005); (Eusébio \& Vieira, 2013) and (A. Azhar \& Iskandarsyah, 2019).

\section{H3: Tourist Experience Affects Significantly Revisit Intention}

The tourists' experience is a positive or negative evaluation performed by tourists in traveling. The study carried out by (Petrick, Morais, \& Norman, 2001) showed that a person tends to repeat their activities if they feel satisfied and have a positive experience when doing these activities. According to previous research conducted by (Cole \& Chancellor, 2009); (Hosany \& Witham, 2009), (Hsu \& Crotts, 2006), tourist experience is directly correlated with revisit intention.

\section{H4: Destination Image Affects Significantly Revisit Intention}

According to (C.-F. Chen \& Tsai, 2007), tourist behavior consists of a combination of 


\section{International Journal of Business Management and Economic Review}

Vol. 4, No. 03; 2021

ISSN: 2581-4664

choosing a destination to visit, followed by the intention and evaluation of revisiting the same place in the future. Evaluation is the value perceived by tourists as experience and satisfaction, while the intention to revisit is a desire in the future to visit the same destination and recommend it to others (Bigné et al., 2001); (Hume \& Mort, 2010); (Som et al., 2012), and (Ridha \& Amalia, 2018).

\section{H5: Tourist Satisfaction Affects Significantly Revisit Intention}

According to (Kozak \& Kozak, 2013), the tendency to revisit intention and tell others (word of mouth) about the positive experiences that are felt are some of the indicators of tourist satisfaction. Studies conducted by (S. Huang \& Hsu, 2009) and (Kuo, 2011), explained that tourist satisfaction has a positive and significant influence on revisit intention.

\section{H6: Tourist Experience Affects Significantly Revisit Intention through Tourist Satisfaction}

The tourist experience is an indicator of consumer behavior that has an impact on increasing tourist revisit intention. (Um et al., 2006) stated that the tourist experience felt by sports participants tends to repeat the same experience in the future. This finding suggests that the tourist intention to revisit is a form of a positive evaluation of the experience during their visit through the satisfaction they feel. The study conducted by (Chan, 2018) concluded that the influence environment, the influence of the physical environment, and the influence of social interaction as independent variables influenced revisit intention on customer satisfaction as a mediating variable.

\section{H7: Destination Image Affects Significantly Revisit Intention through Tourist Satisfaction}

According to (Kozak \& Kozak, 2013), the perception of tourists towards a tourist destination which is the result of an evaluation can affect tourist revisit intention through satisfaction. Similarly, (Lee et al., 2005), also argued that a good destination image can influence the shape of a positive tourist experience increasing tourist satisfaction and revisit intention. Thus, the image of a destination can effectively increase revisit intention through tourist satisfaction.

\section{RESEARCH METHOD}

\section{Location and Research Objects}

The research was conducted at tourism destinations in Aceh Besardistrict. The variables of this research are Tourist experience (TE), Destination image (DI), Tourist satisfaction (TS), and Tourist revisit intention (RI).

\section{Population and Sample}

The population in this study were all tourists visiting tourist destinations in Aceh Besar District. The samples were selected using a simple random sampling technique, where each case population has the same probability of inclusion in the sample (Taherdoost, 2016). The inclusion criteria in this study were respondents who had visited one of the tourist destinations in the Aceh Besar District, such as Lhok Nga Beach, Babah Kuala Beach, UjongBatee Beach, KutaMalaka Water Boom, and other tourist destinations. This study employed the Maximum Likelihood Estimation (MLE) technique. There were 220 respondents chosen as the research sample. 


\section{International Journal of Business Management and Economic Review}

Vol. 4, No. 03; 2021

ISSN: 2581-4664

To measure the revisit intention, this research adopted 4 indicators proposed by (Som et al., 2012). Regarding Tourist satisfaction, this study adopted 5 indicators proposed by (Valle et al., 2006) Moreover, for the tourist experience, 4 indicators based on (Pine \& Gilmore, 2013) were used. Lastly, to measure destination image, the 4 indicators proposed (Qu et al., 2011) were chosen. Therefore, there were 17 indicators used to measure each variable.

To analyze the data in this study, this study used the SEM method with the help of the AMOS application (Hair. Et. Al., 2012). As illustrated in Figure 1, the calculation of the SEM model in this study uses the following equation:

$\mathrm{TS}=\gamma_{11} \mathrm{TE}+\gamma_{12} \mathrm{DI}+\zeta_{1}$

$\mathrm{RI}=\gamma_{21} \mathrm{TE}+\gamma_{22} \mathrm{DI}+\beta_{21} \mathrm{TS}+\zeta_{2}$

Remarks:

$\mathrm{TE}=$ Tourist Experience, $\mathrm{DI}=$ Destination image, $\mathrm{TS}=$ Tourist satisfaction, $\mathrm{RI}=$ Revisit Intention n, $\gamma_{11}$ dan $\gamma_{12}=$ regression TE dan DI towards TS, $\beta_{21}=$ regression TS towards RI dan $\zeta_{2}$ $=$ structural error

\section{FINDING AND DISCUSSION}

Table 1. Respondents Characteristics

\begin{tabular}{|l|l|l|}
\hline Respondent Characteristics & Number (n) & Percentage (\%) \\
\hline Sex & 104 & 47.3 \\
\hline Male & 116 & 52.7 \\
\hline Female & 32 & 14.5 \\
\hline Age & 90 & 40.9 \\
\hline$<25$ Year Old & 68 & 30.9 \\
\hline 26-30 Year Old & 23 & 10.5 \\
\hline 31-35 Year Old & 7 & 3.2 \\
\hline 36-40 Year Old & \multicolumn{2}{|l|}{} \\
\hline$>$ 40 Year Old & 39 & 17.7 \\
\hline Marital Status & 170 & 77.3 \\
\hline Unmarried & 11 & 5 \\
\hline Married & \multicolumn{2}{|l|}{} \\
\hline Widowed & 40 & 18.2 \\
\hline Education Level & 43 & 19.5 \\
\hline Senior High Sch. & 131 & 59.5 \\
\hline Academy/Dipl. & 6 & 2.7 \\
\hline Undergraduate & \multicolumn{2}{|l|}{} \\
\hline Postgraduate & 19 & 16.81 \\
\hline Visit together with & 21 & 18.58 \\
\hline Family & 24 & 21.24 \\
\hline Neighbors & 15 & 13.27 \\
\hline Friends & \multicolumn{2}{|l|}{} \\
\hline Alone &
\end{tabular}




\section{International Journal of Business Management and Economic Review}

Vol. 4, No. 03; 2021

ISSN: 2581-4664

\begin{tabular}{|l|l|l|}
\hline \hline Colleagues & 34 & 30.09 \\
\hline Origin & 214 & 97.3 \\
\hline Domestic & 6 & 2.7 \\
\hline Overseas & \multicolumn{2}{|l|}{} \\
\hline Number of Visit & 40 & 18.2 \\
\hline Once & 102 & 46.4 \\
\hline Twice & 78 & 35.5 \\
\hline More than twice & 175 & 79.5 \\
\hline Tourism Attraction Preference & 9.1 \\
\hline Nature & 20 & 3.6 \\
\hline Cultural & 8 & 7.7 \\
\hline Historical & 17 & \\
\hline Culinary &
\end{tabular}

\section{Descriptive Statistical Analysis}

Descriptive analysis was performed to provide an overview of the perceptions of tourists who have visited one of the tourist destinations in the Aceh BesarDistrict. The results of the analysis showed that the mean respondents' perceptions of the tourist experience variable were 3.95. This result suggests that, in general, tourists had a good perception of their experience. Moreover, the mean of destination image variable, the respondents' perception was 3.79 (ranged in good category). Meanwhile, the mean of the respondents' perspective on the tourist satisfaction variable was 3.84. This figure is in the interval of $3.41-4.20$ (ranged in good category) showing that most of the respondents tend to express the satisfaction they feel when visiting tourist destinations in the Aceh BesarDistrict. Finally, the mean of respondents' perception of the intention to return to visit variable was 3.88. It can be interpreted that tourists generally had a good perception of the intention to return to tourist destinations in the Aceh BesarDistrict. Based on the results of the analysis, it can be concluded that the experience of tourists, the image of the destination, the satisfaction of tourists, and the intention to revisit Aceh BesarDistrict are all in the good category.

\section{Verification Analysis}

\section{CFA Test (Confirmatory Factor Analysis)}

CFA testing aims to measure the indicators that are accurately and consistently conceptualized in forming the construct of the study. The construct CFA test in this study consists of 4 variables, i.e. Tourist experience (TE), Destination image (DI), Tourist satisfaction (TS), and Revisit intention (RI). 
Vol. 4, No. 03; 2021

ISSN: 2581-4664

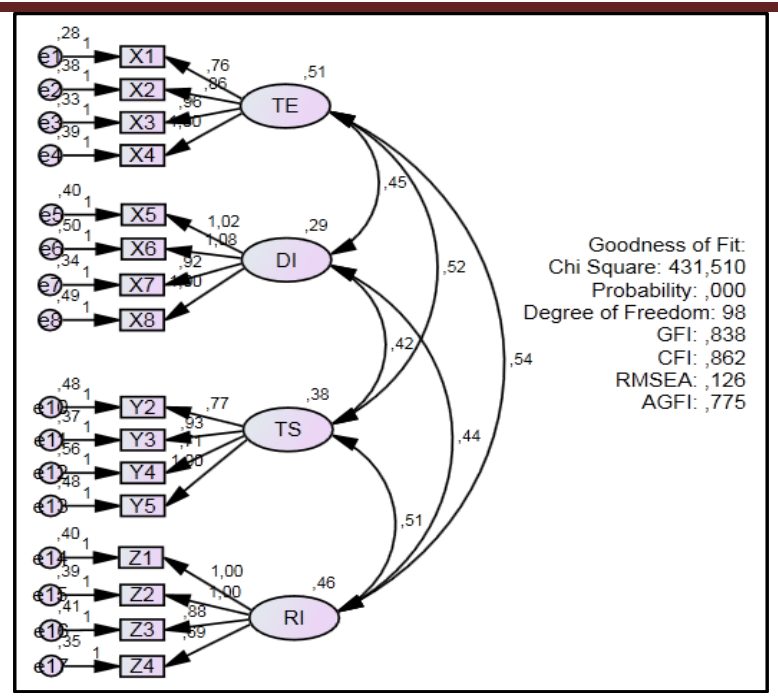

Figure1. CFA Diagram of the Whole Construct Model

Table 2. Goodness of Fit Test Results of Full Model Structure

\begin{tabular}{|l|l|l|l|}
\hline Model Fit & Value & $\begin{array}{l}\text { Cut } \\
\text { Value }\end{array}$ & Of \\
\hline$X^{2}$ Chi-Square (df=94) & 113.063 & $<117.631$ & Fit \\
\hline Probability & 0.088 & $\geq 0.05$ & Fit \\
\hline CMIN/DF & 1.203 & $\leq 2.00$ & Fit \\
\hline RMSEA & 0.030 & $\leq 0.08$ & Fit \\
\hline GFI & 0.940 & $\geq 0.90$ & Fit \\
\hline AGFI & 0.913 & $\geq 0.90$ & Fit \\
\hline CFI & 0.992 & $\geq 0.90$ & Fit \\
\hline
\end{tabular}

Based on Figure 1 about the CFA diagram and table 2, it can be observed that all the results of the full model structure test showed good goodness of fit as they have met the recommended values. Therefore, the model in this study has met the goodness of fit criteria and is feasible to be tested using the SEM analysis. The results of the calculation of the structural model estimate can be seen in the following figure and table. 


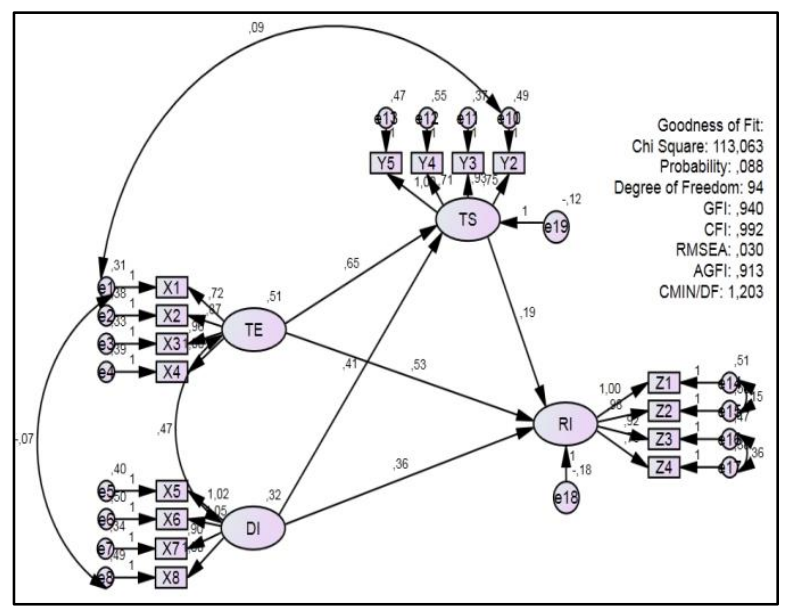

Figure 2. Full Model Structure

Table 3. Structural Model Estimation Results

\begin{tabular}{|l|l|l|l|l|l|l|}
\hline \multicolumn{2}{|l|}{ Variable } & Estimate & S.E. & C.R. & P \\
\hline TS & $<---$ & TE &, 651 &, 074 & 8,814 & $* * *$ \\
\hline TS & $<---$ & DI &, 415 &, 078 & 5,317 & $* * *$ \\
\hline RI & $<---$ & TE &, 527 &, 065 & 8,074 & $* * *$ \\
\hline RI & $<---$ & DI &, 288 &, 053 & 5,403 & $* * *$ \\
\hline RI & $<---$ & TS &, 233 &, 045 & 5,130 & $* * *$ \\
\hline
\end{tabular}

\section{Direct Effect Hypothesis Testing}

\section{Tourist experience In Affecting tourist satisfaction (H1 Hypothesis)}

From Figure 2 and Table 3, it can be observed that the significance value of the influence of the tourist experience variable on tourist satisfaction is $* * *(* * *$ it is assumed that the value is very small, close to 0.000 , which means that $* * *$ is smaller than 0.05 ), with loading estimate positive sign of 0.651. These two values represent the C.R. of 8.814> 1.96 and the standardized loading estimate value is positive indicating that the tourist experience variable has a positive and significant effect on tourist satisfaction. These results are consistent with the results of research conducted by (Martín-Ruiz, Castellanos-Verdugo, \& ÁngelesOviedo-García, 2010), (Jin, Lee, \& Lee, 2015), and (N. H. Azhar \& Anuar, 2019).

\section{Destination Image In Affecting Tourist Satisfaction (H2 Hypothesis)}

From Figure 2 and Table 3, it is shown that the significance value of the influence of Destination Image (DI) on tourist satisfaction (TS) is ***, with apositive loading estimate of 0.415. These two values represent the C.R. of 5.317 above 1.96 and the standardized loading estimate value is positive indicating that the Destination Image variable has a positive and significant effect on tourist satisfaction.The results ofhypothesis testing are supported by the results of previous research conducted by (Chou, 2013) which concluded that destination image 


\section{International Journal of Business Management and Economic Review}

Vol. 4, No. 03; 2021

ISSN: 2581-4664

has a positive and significant relationship to tourist satisfaction.

\section{Tourist Experience In Affecting the Revisit Intention (H3 Hypothesis)}

From Figure 2 and Table 3, it can be seen that the significance value of the effect of the tourist experience (TE) variable on the revisit intention(RI) is ***, with a positive loading estimate of 0.233 . These two values represent the C.R. value of 8.074 above 1.96 and the value of the standardized loading estimate is positive which indicates that the tourist experience variable has a positive and significant effect on the revisit intention. These results are in line with research conducted by (Shen, 2016), (Wang, Wu, \& Yuan, 2010), and (Yuniawati \& Finardi, 2016).

\section{Destination Image In AffectingRevisit Intention (H4 Hypothesis)}

From Figure 2 and Table 3, it can be observed that the significance value of the influence of the variable influence of Destination Image (DI) on Revisit Intention (RI) is ***, with a positive loading estimate of 0.288 . These two values represent the C.R. value of 5.043 above 1.96 and the value of the standardized loading estimate is positive that indicates the destination image has a positive and significant effect on revisit intention. These results are also in agreement with research conducted by (Ridha \& Amalia, 2018), (Kim \& Lee, 2015) which all report that image has an important role in giving a good impression on tourists and can increase tourists' intention to visit the same destination.

\section{Tourist Satisfaction In AffectingRevisit Intention (H5 Hypothesis)}

From Figure 2 and Table 3, it is shown that the significance value of the influence of the tourist satisfaction (TS) variable on Revisit Intention (RI) is ***, with a positive loading estimate of 0.288. These two values represent the C.R. value of 5,130 above 1.96 and the standardized loading estimate value is positive suggesting that the variable influence of tourist satisfaction has a positive and significant effect on revisit intention. These results are supported by the research conducted by (N. Chen \& Funk, 2010), (Guntoro \& Hui, 2013), (Raza, Siddiquei, Awan, \& Bukhari, 2012) and (Chan, 2018).

\section{Mediation Effect Hypothesis Test}

Based on the test results of the direct effect and the indirect effect, it can be described as in the following figure: 


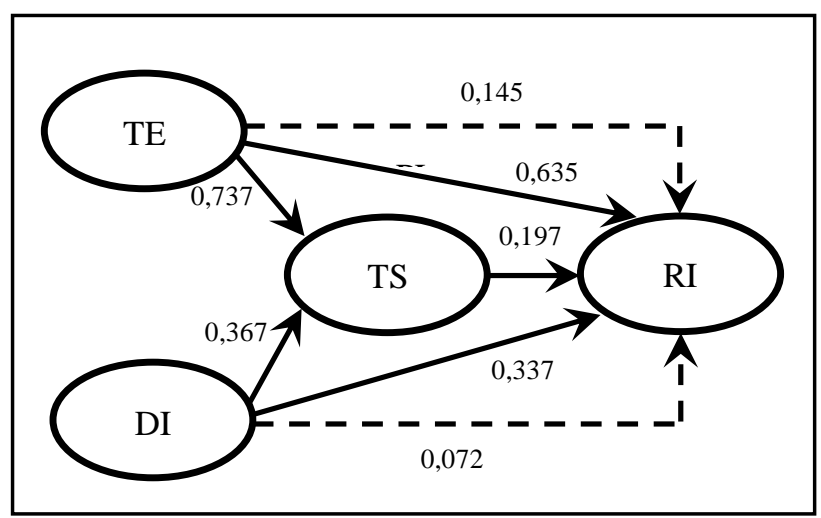

Figure 3. Test of Direct and Indirect Effect

Table 4. Indirect Effect Test

\begin{tabular}{|l|llll|}
\hline & DI & TE & TS & RI \\
\hline TS & 0.000 & 0.000 & 0.000 & 0.000 \\
RI & 0.072 & 0.145 & 0.000 & 0.000 \\
\hline
\end{tabular}

Tourist Experience In Affecting the Tourist Revisit Intention through Tourist Satisfaction (H6 Hypothesis)

From figure 3 and table 4, it can be observed that the test of the indirect effect of the tourist experience variable on the revisit intention through tourist satisfaction shows a coefficient of 0.145 . This indicates that the tourist experience variable has a positive effect on the revisit intention through tourist satisfaction. Also, it shows that the direct effect of tourist experience on the tourist revisit intention is greater than the indirect effect of tourist experience on returning intention through tourist satisfaction $(0.635>0.145)$. It means that the direct effect can influence more than the indirect effect. And in this model, tourist satisfaction is shown to act as a partial mediation. The studies carried out by (C.-F. Chen \& Chen, 2010) and (N. H. Azhar \& Anuar, 2019), also found that tourist satisfaction mediates the relationship between the quality of tourist experience and tourist behavior intentions.

\section{Destination image In Affecting the tourist revisit intention through tourist satisfaction (H7 Hypothesis)}

Based on figure 3 and Table 4, it can be seen that the test of the indirect influence of the destination image variable on the revisit intention through tourist satisfaction shows the coefficient of0.072. This indicates that the destination image variables have a positive effect on the revisit intention through tourist satisfaction. Also, it showsthe direct effect of destination image on the revisit intention is greater than the indirect effect of the image of the destination towards the revisit intention through tourist satisfaction $(0.337>0.072)$. It means that the direct effect can influence more than the indirect effect. And in this model, tourist satisfaction is shown to act as a partial mediation. The results of this study are consistent with research conducted by (Beerli, Martín, \& Quintana, 2004) and (Bigné et al., 2001). 


\section{CONCLUSIONS}

This study proves that Tourists' experience Affects Significantly tourists' satisfaction, Destination Image Affects Significantly Tourist Satisfaction, Tourist Experience Affects Significantly Revisit Intention, Destination Image Affects Significantly Revisit Intention, Tourist Satisfaction Affects Significantly Revisit Intention, Tourist Experience Affects Significantly Revisit Intention through Tourist Satisfaction, and Destination Image Affects Significantly Revisit Intention through Tourist Satisfaction. These results indicate that the evidence of the research model that has been carried out is still following previous theories of causality, especially on the object under study. The novelty of the research is in a combination of previous causality theories which are combined into a model to be investigated on new objects. These results contribute to the world of academia, which can be a reference for further researches. For further research, it is hoped that it will be able to develop a research model by adding new variables such as destination image or tourist gender. Besides, the research location and different characteristics of respondents in the analysis will also enrich the existing empirical evidence about the effect of tourist experience and destination image on revisit intention through tourist satisfaction.

\section{REFERENCES}

Ajzen, I. (2002). Perceived behavioral control, self-efficacy, locus of control, and the theory of planned behavior. Journal of Applied Social Psychology, 32(4), 665-683. https://doi.org/https://doi.org/10.1111/j.1559-1816.2002.tb00236.x

Azhar, A., \& Iskandarsyah. (2019). Pengaruh Ekspektasi, Persepsi Kualitas, Persepsi Nilai Dan Citra Tujuan Wisata Terhadap Kepuasan Wisatawan Pada Pulau Weh Sabang. Jurnal Ilmiah Mahasiswa Ekonomi Manajemen, 4(4), 562-574.

Azhar, N. H., \& Anuar, N. A. M. (2019). Experience Quality, Satisfaction, and Behavioral Intention among the Visitors of Taman Tamadun Islam (TTI), Terengganu, Malaysia. Journal of Accounting Research, Organization and Economics, 2(3), 184-192. https://doi.org/https://doi.org/10.24815/jaroe.v2i3.15342

Baloglu, S., \& Brinberg, D. (1997). Affective Images of Tourism Destinations. Journal of Travel Research, 35(4), 11-15. https://doi.org/https://doi.org/10.1177/004728759703500402

Beerli, A., Martín, J. D., \& Quintana, A. (2004). A model of customer loyalty in the retail banking market. European Journal of Marketing, 38(1/2), 253-275. https://doi.org/https://doi.org/10.1108/03090560410511221

Bigné, J. E., Sánchez, M. I., \& Sánchez, J. (2001). Tourism image, evaluation variables and after purchase behaviour: inter-relationship. Tourism Management, 22(6), 607-616. https://doi.org/https://doi.org/10.1016/S0261-5177(01)00035-8

Chan, S. (2018). Factors Affecting Revisit Intention With Customer Satisfaction As A Mediating Variable In Eco Friendly Resorts. Jurnal Manajemen Inovasi, 9(1), 1-13.

Chen, C.-F., \& Chen, F.-S. (2010). Experience quality, perceived value, satisfaction and behavioral intentions for heritage tourists. Tourism Management, 31(1), 29-35. 


\section{International Journal of Business Management and Economic Review}

Vol. 4, No. 03; 2021

ISSN: 2581-4664

https://doi.org/https://doi.org/10.1016/j.tourman.2009.02.008

Chen, C.-F., \& Tsai, D. C. (2007). How destination image and evaluative factors affect behavioral intentions? Tourism Management, 28(4), 1115-1122. https://doi.org/https://doi.org/10.1016/j.tourman.2006.07.007

Chen, N., \& Funk, D. C. (2010). Exploring Destination Image, Experience and Revisit Intention: A Comparison of Sport and Non-Sport Tourist Perceptions. Journal of Sport Tourism, 15(3), 239-259. https://doi.org/10.1080/14775085.2010.513148

Chou, H.-J. (2013). Impact of Recreation Experience and Tourism Attractiveness on Tourist Satisfaction and Intention to Revisit-An Example of Kenting National Park in Taiwan. International Journal of Business and Behavioral Sciences, 3(11), 36-53.

Cole, S., \& Chancellor, H. C. (2009). Examining the Festival Attributes That Impact Visitor Experience, Satisfaction and Re-visit Intention. Journal Of Vacation Marketing, 15(4), 323333. https://doi.org/10.1177/1356766709335831

Eusébio, C., \& Vieira, A. L. (2013). Destination Attributes' Evaluation, Satisfaction and Behavioural Intentions: a Structural Modelling Approach. International Journal of Tourism Research, 15(1), 66-80. https://doi.org/https://doi.org/10.1002/jtr.877

Gaspersz, V. (2005). Sistem manajemen kinerja terintegrasi balanced scorecard dengan six sigma untuk organisasi bisnis dan pemerintah. Jakarta: Gramedia Pustaka Utama.

Guntoro, B., \& Hui, T.-K. (2013). Travel Satisfaction and Revisit Intention of Chinese Visitors: The Case of Singapore. Advances in Hospitality and Leisure, 9, 29-47. https://doi.org/https://doi.org/10.1108/S1745-3542(2013)0000009006

Hosany, S., \& Witham, M. (2009). Dimensions of Cruisers' Experiences, Satisfaction, and Intention to Recommend. Journal of Travel Research, 49(3), 351-364. https://doi.org/10.1177/0047287509346859

Hsu, C. H. C., \& Crotts, ohn C. (2006). Segmenting mainland Chinese residents based on experience, intention and desire to visit Hong Kong. International Journal of Tourism Research, 8(4), 279-287. https://doi.org/10.1002/jtr.575

Huang, C.-C., Yen, S.-W., Liu, C.-Y., \& Chang, T.-P. (2014). The Relationship Among Brand Equity, Customer Satisfaction, and Brand Resonance to Repurchase Intention of Cultural and Creative Industries in Taiwan. International Journal of Organizational Innovation, 6(3), 106-120.

Huang, S., \& Hsu, C. H. C. (2009). Effects of Travel Motivation, Past Experience, Perceived Constraint, and Attitude on Revisit Intention. Journal of Travel Research, 48(1), 29-44. https://doi.org/https://doi.org/10.1177/0047287508328793

Hume, M., \& Mort, G. S. (2010). The consequence of appraisal emotion, service quality, perceived value and customer satisfaction on repurchase intent in the performing arts. Journal of Services Marketing, 24(2), 170-182. https://doi.org/https://doi.org/10.1108/08876041011031136 
Vol. 4, No. 03; 2021

ISSN: 2581-4664

Jin, N. P., Lee, S., \& Lee, H. (2015). The Effect of Experience Quality on Perceived Value, Satisfaction, Image and Behavioral Intention of Water Park Patrons: New Versus Repeat Visitors. International Journal of Tourism Research, 17(1), 82-95. https://doi.org/10.1002/jtr.1968

Kastenholz, E., Carneiro, M. J., Marques, C. P., \& Loureiro, S. M. C. (2018). The dimensions of rural tourism experience: impacts on arousal, memory, and satisfaction. Journal of Travel \& Tourism Marketing, 35(2),

https://doi.org/https://doi.org/10.1080/10548408.2017.1350617

Kim, H., \& Lee, S. (2015). Impacts of city personality and image on revisit intention. International Journal of Tourism Cities, 1(1), 50-69. https://doi.org/https://doi.org/10.1108/IJTC-08-2014-0004

Kozak, M., \& Kozak, N. (2013). Aspects of Tourist Behavior. Britania Raya: Cambridge Scholars Publishing; Unabridged edition.

Kozak, M., \& Rimmington, M. (2000). Tourist Satisfaction With Mallorca, Spain, as an OffSeason Holiday Destination. Journal of Travel Research, 38(3), 260-269. https://doi.org/10.1177/004728750003800308

Kuo, C.-T. (2011). Tourist Satisfaction and Intention to Revisit Sun Moon Lake. The Journal of International Management Studies, 6(1), 1-6. Retrieved from http://www.jimsjournal.org/4 Chin-Tsai Kuo.pdf

Lee, C.-K., Lee, Y.-K., \& Lee, B. (2005). Korea's destination image formed by the 2002 World Cup. Annals of Tourism Research, 32(4), 838-858. https://doi.org/https://doi.org/10.1016/j.annals.2004.11.006

Lin, C.-H. (2012). Effects of Cuisine Experience, Psychological Well-Being, and Self-Health Perception on the Revisit Intention of Hot Springs Tourists. Journal of Hospitality \& Tourism Research, 38(2), 243-265. https://doi.org/https://doi.org/10.1177/1096348012451460

Mai, L.-W., \& Ness, M. R. (2006). A Structural Equation Model of Customer Satisfaction and Future Purchase of Mail-Order Speciality Food. International Journal of Business Science and Applied Management, 1(1), 1-13.

Martín-Ruiz, D., Castellanos-Verdugo, M., \& ÁngelesOviedo-García, de los. (2010). A visitors' evaluation index for a visit to an archaeological site. Tourism Management, 31(5), 590-596. https://doi.org/https://doi.org/10.1016/j.tourman.2009.06.010

Oh, H., Fiore, A. M., \& Jeong, M. (2007). Measuring Experience Economy Concepts: Tourism Applications. Journal of Travel Research, 46(2), 119-132. https://doi.org/https://doi.org/10.1177/0047287507304039

Petrick, J., Morais, D., \& Norman, W. (2001). An Examination of the Determinants of Entertainment Vacationers' Intentions to Revisit. Journal of Travel Research, 40(1), 41-48. https://doi.org/10.1177/004728750104000106

Pine, B. J., \& Gilmore, J. H. (2013). The experience economy: past, present and future. In 


\section{International Journal of Business Management and Economic Review}

Vol. 4, No. 03; 2021

ISSN: 2581-4664

Handbook on the Experience Economy (pp. 21-44).

https://doi.org/https://doi.org/10.4337/9781781004227.00007

Pratminingsih, S. A., Rudatin, C. L., \& Rimenta, T. (2014). Roles of Motivation and Destination Image in Predicting Tourist Revisit Intention: A Case of Bandung-Indonesia. International Journal of Innovation, Management and Technology, 5(1), 19-24. https://doi.org/10.7763/IJIMT.2014.V5.479

Qu, H., Kim, L. H., \& Im, H. H. (2011). A model of destination branding: Integrating the concepts of the branding and destination image. Tourism Management, 32(3), 465-476. https://doi.org/https://doi.org/10.1016/j.tourman.2010.03.014

Quintal, V., \& Phau, I. (2008). A structural approach towards perceptions and satisfaction of revisit intentions. Proceedings of Australian and New Zealand Marketing Academy Conference 2008, 1-8. Retrieved from http://hdl.handle.net/20.500.11937/45156

Rajesh, R. (2013). Impact of Tourist Perceptions, Destination Image and Tourist Satisfaction on Destination Loyalty: A Conceptual Model. Pasos. Revista de Turismo y Patrimonio Cultural, 11(3), 67-78. https://doi.org/10.25145/j.pasos.2013.11.039

Raza, M. A., Siddiquei, A. N., Awan, H. M., \& Bukhari, K. (2012). Relationship Between Service Quality, Perceived Value, Satisfaction And Revisit Intention In Hotel Industry. Interdisciplinary Journal Of Contemporary Research in Business, 4(8), 788-805.

Richard, O., \& Vanessa. (2007). Satisfaction: A Behavioral Perpective On The Consumer. New York: The McGraw-Hill Companise, Inc.

Ridha, M., \& Amalia, R. (2018). Citra Tujuan Wisata Dan Citra Kuliner Aceh Serta Pengaruhnya Terhadap Niat Wisatawan Untuk Kembali Mengunjungi Kota Banda Aceh. Jurnal Ilmiah Mahasiswa Ekonomi Manajemen, 3(4), 137-146. Retrieved from http://jim.unsyiah.ac.id/EKM/article/view/652

Ryan, C., \& Glendon, I. (1998). Application of Leisure Motivation Scale to Tourism. Annals of Tourism Research, 25(1), 169-184. https://doi.org/https://doi.org/10.1016/S01607383(97)00066-2

Semrad, K. J., \& Rivera, M. (2018). Advancing the 5E's in festival experience for the Gen Y framework in the context of eWOM. Journal of Destination Marketing and Management, 7, 58-67. https://doi.org/https://doi.org/10.1016/j.jdmm.2016.08.003

Shen, Y. S. (2016). Perceived Value in Tourism Experience Expectations: Questionnaire Development and Text Narrative Analysing. International Journal of Culture, Tourism and Hospitaly Research, 7(1), 93-104.

Som, A. P. M., Marzuki, A., Yousefi, M., \& AbuKhalifeh, A. N. (2012). Factors Influencing Visitors' Revisit Behavioral Intentions: A Case Study of Sabah, Malaysia. International Journal of Marketing Studies, 4(4), 39-50. https://doi.org/10.5539/ijms.v4n4p39

Sulastri, Rapini, T., \& Kristiyana, N. (2018). Analisis Pengaruh Daya Tarik, Kualitas Pelayanan Terhadap Minat Berkunjung Ulang Pengunjung Yang Berkunjung Di Mojosemi Forest Park Kabupaten Magetan Dengan Kepuasan Pengunjung Sebagai Variabel Interveninganalisis 


\section{International Journal of Business Management and Economic Review}

Vol. 4, No. 03; 2021

ISSN: $2581-4664$

Pengaruh Dayak Tarik, Kualitas Pelayanan . ISOQUANT Jurnal Ekonomi Manajemen Dan Akuntansi, 2(2), 37-45. https://doi.org/10.24269/iso.v2i2.196

Taherdoost, H. (2016). Sampling Methods in Research Methodology; How to Choose a Sampling Technique for Research. SSRN Electronic Journal, 5(2), 18-27. https://doi.org/10.2139/ssrn.3205035

Tse, D. K., \& Wilton, P. C. (1988). Models of Consumer Satisfaction Formation: An Extension. Journal of Marketing Research, 25(2), 204-212. https://doi.org/https://doi.org/10.2307/3172652

Um, S., Chon, K., \& Ro, Y. H. (2006). Antecedents of revisit intention. Annals of Tourism Research, 33(4), 1141-1158. https://doi.org/https://doi.org/10.1016/j.annals.2006.06.003

Valle, P. O. do, Silva, J. A., Mendes, J., \& Guerreiro, M. (2006). Tourist Satisfaction and Destination Loyalty intention: A Structural and Categorical Analysis. Int. Journal of Business Science and Applied Management, 1(1), 25-44.

Wang, Y., Wu, C. (Kenny), \& Yuan, J. (Jessica). (2010). Exploring Visitors' Experiences and Intention to Revisit a Heritage Destination: The Case for Lukang, Taiwan. Journal of Quality Assurance in Hospitality \& Tourism, 11(3), 162-178. https://doi.org/https://doi.org/10.1080/1528008X.2010.483418

Yoon, Y., \& Uysal, M. (2005). An examination of the effects of motivation and satisfaction on destination loyalty: a structural model. Tourism Management, 26(1), 45-56. https://doi.org/https://doi.org/10.1016/j.tourman.2003.08.016

Yuniawati, Y., \& Finardi, A. D. I. (2016). Pengaruh Customer Experience Terhadap Revisit Intention Di Taman Wisata Alam Gunung Tangkuban Perahu. The Journal: Tourism and $\begin{array}{llll}\text { Hospitality Essentials } & \text { Journal, } & \text { 6(1), }\end{array}$ https://doi.org/https://doi.org/10.17509/thej.v6i1.2009

Zhang, H., Wu, Y., \& Buhalis, D. (2018). A model of perceived image, memorable tourism experiences and revisit intention. Journal of Destination Marketing \& Management, 8, 326336. https://doi.org/https://doi.org/10.1016/j.jdmm.2017.06.004 